\title{
KARAKTERISTIK SIFAT FISIK TANAH PADA LAHAN BUDIDAYA UBI KAYU (Manihot Esculenta Crantz) DI DESA WOLOGAI TENGAH
}

\author{
Mariana Umin dan Agustinus J.P.Anasaga \\ Program Studi Agroteknologi, Fakultas Pertanian, Universitas Flores \\ Kampus I, Jln. Sam Ratulagi XX, Paupire, Kabupaten Ende Nusa Tenggara Timur \\ needysagga@gmail.com
}

\begin{abstract}
Characteristics of physical properties of land on wood culture (Manihot esculenta crantz) in Central Wologai Village. Characteristics of soil physical properties are the diversity of soil conditions based on structure, texture, soil color, and soil moisture content. Features of the physical properties of the soil influenced by several factors, including poor land management, which results in a decrease in fertility levels that includes physical, chemical, and biological soil characteristics.

The method used in this study is the sample cluster method. Consists of a small group of units and then randomly selected as a representative of the population, all elements in the chosen cluster used as research samples. This study aims to determine the physical characteristics of soil texture, soil structure, soil color, and soil moisture content in cassava (Manihot esculenta Crantz) in Wologai Tengah Village.

The results showed that the texture of the soil in cassava soil dominated by clay texture. The structure of the angular lumpy ground, soil color 10 YR 2/1 Black, and 10 YR $2 / 2$ Very Dark Brown and had a soil moisture content of $37.4 \%$. This soil type is an ideal soil type or classified as fertile to cultivate cassava plants.
\end{abstract}

Keywords : Characteristics of soil physic, Cassava

\section{PENDAHULUAN}

\section{Latar Belakang}

Sifat fisik tanah merupakan sifat tanah yang berhubungan dengan bentuk/ kondisi tanah asli diantaranya adalah tekstur tanah, stuktur tanah, warna tanah, kadar air tanah, suhu tanah dan lain-lain. Sifat fisik tanah juga merupakan faktor yang sangat berpengaruh terhadap tersedianya air, udara tanah dan secara tidak langsung mempengaruhi ketersediaan unsur hara tanaman, yang akan mempengaruhi potensi tanah untuk berproduksi secara maksimal (Naldo, 2011). Kerusakan sifat fisik tanah yang perlu mendapat perhatian serius adalah masalah degradasi struktur tanah akibat berubahnya warna tanah, partikel pasir, debu, liat dan kadar air akibat kesalahan dalam pengelolaan tanah (Wirosoedarmo, 2013) namun demikian lahan yang tidak tererosi juga bisa hilang bahan organiknya kondisi yang demikian ditemukan di Missouri Agricultural Experiment Station dimana praktik budidaya yang dilakukan lebih dari 60 tahun dan tanah pada 
keadaan yang tidak tererosi ternyata bahan organik dapat hilang sepertiganya, kehilangan tersebut lebih besar pada awal budidaya dibandingkan budidaya selanjutnya. Kehilangan bahan organik sekitar 25\% pada 20 tahun awal, sekitar $10 \%$ pada 20 tahun kedua dan hanya sekitar 7\% pada 20 tahun ketiga (Wirosoedarmo, 2013).

Sifat fisik tanah perlu diperhatikan dan diketahui karakteristiknya untuk menjaga tanah terutama dari kerusakan yang mungkin terjadi apabila lahan tersebut digunakan, beberapa diantaranya yaitu tekstur, warna, kadar air dan strukrur tanah. Sifat fisik tanah berbeda dari suatu tempat ke tempat lain. Perbedaan tersebut disebabkan oleh perbedaan faktor pembentuk tanah, yakni iklim, bahan induk, organisme, topografi dan waktu. Pada tanah dengan kondisi iklim, bahan induk dan organisme yang sama, sifatsifat tanah akan dipengaruhi oleh topografi, karena waktu merupakan faktor yang pasif, maka selain bahan induk, sifatsifat tanah akan lebih dominan dipengaruhi oleh topografi (Rusdiana, 2012).

Struktur tanah merupakan partikelpartikel tanah seperti pasir, debu, dan liat yang membentuk agregat tanah antara suatu agregat dengan agregat yang lainnya. Dengan kata lain struktur tanah berkaitan dengan agregat tanah dan kemantapan agregat tanah. Bahan organik berhubungan erat dengan kemantapan agregat tanah karena bahan organik bertindak sebagai bahan perekat antara partikel mineral primer, (Putra, 2009).
Pertumbuhan tanaman secara tidak langsung dapat dipengaruhi oleh tekstur tanah. Kondisi tersebut dipengaruhi oleh kemampuan tekstur tanah dalam menyimpan dan mengantar air serta menyimpan dan menyediakan hara tanaman. Ciri tanah bertekstur pasir memiliki kandungan pasir $>70 \%$, porositasnya $<40 \%$, sebagian ruang pori berukuran besar sehingga aerasinya baik, daya hantar air cepat, tetapi kemampuan menyimpan zat hara rendah dan mudah di olah. Ciri tanah bertekstur liat yaitu $>35 \%$ kemampuan menyimpan air dan hara tanah tinggi. Tanah liat juga disebut dengan tanah berat karena sulit diolah. Ciri tanah berdebu adalah kandungan debu $>25 \%$ (Mahi, 2013).

Warna tanah merupakan komposisi dari warna semua komponen-komponen penyusunnya yang disebabkan oleh proses, karat dan gley. Warna tanah dapat meliputi putih, merah, coklat, kelabu, kuning, hitam, kebiruan dan kehijauan. Warna pada tanah tua merupakan indikator iklim makro ataupun mikro tempat berkembangnya tanah, sedangkan pada tanah muda mencerminkan bahan induk dari tanah tersebut. Pada kondisi tertentu warna tanah juga dijadikan indikator kesuburan atau produktivitas lahan. Warna tanah juga dapat dipengaruhi oleh kandungan bahan organik tanah. Tanah yang mengandung bahan organik tinggi akan berwarna gelap, sebaliknya semakin rendah kandungan bahan organik maka tanah akan berwarna semakin terang akumulasi dari bahan organik akan menciptakan warna 
kehitaman pada suatu tanah atau lahan. Warna gelap pada tanah umumnya disebabkan juga oleh kandungan tinggi dari bahan organik yang terdekomposisi, jadi persentase bahan organik di dalam tanah diestimasi berdasarkan waktu (Mahi, 2013).

Kadar air merupakan banyaknya air yang terkandung dalam bahan yang dinyatakan dalam persen, kandungan air pada suatu bahan yang dapat di nyatakan berdasarkan berat basah (wet basis) atau berdasarkan berat kering (dry basis). Kadar air berat basah mempunyai batas maksimum teoritis sebesar 100\%. Sedangkan kadar air berdasarkan berat kering dapat lebih dari 100\%. Kadar air suatu bahan biasanya dinyatakan dalam persentase berat bahan basah, misalnya dalam gram air untuk setiap 100 gr bahan disebut kadar air berat basah. Berat bahan kering adalah berat bahan setelah mengalami pemanasan beberapa waktu tertentu sehingga beratnya tetap (konstan). Pada proses pengeringan air yang terkandung dalam bahan tidak dapat seluruhnya diuapkan (Hutami, 2014).

Ubi kayu atau singkong (Manihot esculenta Crantz.) merupakan salah satu tanaman pangan daerah tropis yang tumbuh di Indonesia dan merupakan makanan pokok. Ubi kayu (Manihot Esculnta Crantz) sebagai tanaman penghasil karbohidrat tinggi, Ubi kayu (Manihot Esculnta Crantz) merupakan salah satu hasil pertanian yang mengandung karbohidrat dan sumber kalori yang cukup tinggi (161 Kkal), umbinya mengandung air sekitar 60\%, pati (25-35\%), protein, mineral, serat, kalsium dan fosfat (Noerwijati dan Mejaya, 2015).

Produksi ubi kayu (Manihot Esculenta Crantz) di Indonesia tahun 2015 sebesar 21,801 juta ton. Sementara produksi ubi kayu di propinsi NTT pada tahun 2015 sebesar 3,161 dan tahun 2014 sebesar 3,635 juta ton (BPS propinsi, 2015). Dari data ubi kayu yang ada nilai produksi terlihat menurun pada tahun 2015 di bandingkan dengan 2014. Hal ini terjadi karena kesuburan tanah pada wilayah pembudidayaan ubi kayu sudah terpengaruh dengan pemberian pupuk kimia yang berlebihan, sehinggah kesuburan tanah menjadi berkurang atau semakin menurun. Dilihat dari kondisi sifat fisik tanah salah satu solusi untuk meningkatkan hasil produksi ubi kayu di Indonesia, yakni sering menggunakan pupuk organik sehingga sifat fisik tanah tetap terjaga (Hanafiah, 2010).

\section{METODE PENELITIAN}

\section{Tempat Dan Waktu}

Penelitian dilaksanakan di Desa Wologai Tengah Kecamatan Detusoko, Kabupaten Ende, Dengan ketinggian tempat sekitar 1.045 mdpl (Ebed de Rosary, 2017), alasan pilih di desa Wologai Tengah karena penghasilan ubi kayu rendah, pemakaian pestisida yang berlebihan dan pengolahan lahan yang kurang baik, Penelitian ini dilaksanakan selama 6 bulan.

\section{Bahan Dan Alat}


Bahan yang digunakan adalah sampel tanah. Alat yang digunakan adalah patok sampel, ring sampel, alat bor, kantong plastik, parang, buku munsel alat tulis dan kamera.

\section{Pelaksanaan Penelitian \\ Penentuan Lokasi}

Penentuan lokasi didasarkan pada banyaknya kandungan bahan kasar tanah yang ada pada lahan tersebut. Banyaknya kandungan bahan kasar pada lahan dikategorikan dari sangat sedikit, sedikit, sedang, banyak, dan sangat banyak. Pemilihan lokasi penelitian ditentukan dengan metode cluster sampel. Cluster sampel adalah teknik memilih sebuah sampel dari kelompok-kelompok unit yang kecil kemudian cluster di pilih secara acak sebagai wakil dari populasi kemudian seluruh elemen dalam cluster terpilih dijadikan sebagai sampel penelitian.

\section{Teknik Pengambilan Sampel Tanah}

Teknik pengambilan sampel ditentukan secara acak dengan menggunakan ring sampel dan diambil lima titik sampel yang berbeda. Pengambilan sampel tanah pada setiap lokasi dilakukan dengan kedalaman \pm 20 cm. Sampel tanah yang dapat diambil berupa sampel tanah utuh/alami dan tanah terganggu. Sampel tanah alami/utuh diambil dengan menggunakan ring sampel sedangkan sampel tanah terganggu diambil dengan menggunakan cangkul dan skop.

\section{Variabel Pengamatan}

\section{Sifat Fisik Tanah}

Tekstur Tanah. Penetapan tekstur tanah dilakukan dengan analisis mekanis dan menggunakan metode kualitatif basah. Dengan menggunakan metode kualitatif basah fraksi-fraksi tanah dibedakan berdasar waktu kecepatan jatuh yang dibagi menjadi tiga kelompok, yaitu: a) Fraksi pasir merupakan partikel yang turun ke dasar suspensi dalam waktu kurang dari 40 detik. b) Fraksi debu kurang dari 40 detik hingga waktu 2 jam. c) Sisanya yang masih tersupsensi merupakan fraksi liat. Presentasi hasil penetapan masing-masing fraksi tanah ini kemudian dicocokan dengan segitiga tekstur. Cara penggunaan segitiga tekstur misalkan suatu tanah mengandung 50\% pasir, 20\% debu dan 30\% liat. Dari segitiga tekstur dapat di lihat bahwa sudut kanan bawah segitiga menggambarkan 0\% pasir dan sudut kirinya $100 \%$ pasir. Temukan titik $50 \%$ pasir pada sisi dasar segitiga dan dari titik ini tarik garis sejajar dengan sisi kanan segitiga (ke kiri atas) . Kemudian temukan titik 20\% debu pada sisi kanan segitiga. Dari titik ini tarik garis sejajar dengan sisi kiri segitiga, sehingga garis ini berpotongan dengan garis pertama. Kemudian temukan titik 30\% liat dan tarik garis ke kanan sejajar dengan sisi dasar segitiga sehingga memotong dua garis sebelumnya. Dari perpotongan ketiga garis ini, ditemukan bahwa tanah ini mempunyai kelas tekstur "lempung liat berpasir". Salah satu kelas tekstur tanah adalah lempung yang letak disekitar pertengahan tekstur. Dari perpotongan ketiga garis ini, ditemukan bahwa ketiga tanah ini mempunyai kelas tekstur 
"lempung liat berpasir". Salah satu kelas tekstur tanah adalah lempung yang letaknya disekitar pertengahan segitiga tekstur. Lempung mempunyai komposisi yang imbang antara fraksi kasar dan fraksi halus dan lempung sering dianggap sebagai tekstur yang optimal. Hal ini disebabkan oleh kapasitasnya menyerap hara pada umumnya lebih baik dari pada pasir sementara drainase, aerasi dan kemudahannya diolah lebih baik dari pada liat. Misalnya satu tanah setelah diukurkan bahwa kualitatif basahnya ternyata mengadung $50 \%$ pasir, $20 \%$ debu, dan $30 \%$ liat. Untuk menentukan tekstur tanah tersebut dapat dilakukan dengan mencocokan data hasil analisi ketiga fraksi tanah tersebut pada gambar segi tiga tekstur.

\section{Struktur Tanah}

Struktur tanah dianalisis dengan metode kualititaf yaitu tanah yang akan ditentukan struktur diambil dalam bentuk bongkahan, kemudian diamati bentuknya dan tingkat perkembangan struktur.

\section{Warna Tanah}

Cara menentukan warna tanah adalah dengan membandingkan warna tanah dengan warna pembanding dalam kartu Munsell Soil Color Chart, dengan mendekatkan contoh tanah atau memasukkan contoh tanah ke dalam lubang yang telah tersedia didekat masing-masing kertas warna pembanding. Penulisan warna ditulis menurut urutan hue, value, chroma, misalnya 10 YR 2/1 black.

\section{Kadar Air}

Kadar air adalah persentase kandungan air suatu bahan yang dapat dinyatakan berdasarkan berat basah (wet basis) atau berdasarkan berat kering (dry basis). Prosedur kerja yang dilakukan pada pengamatan ini dengan cara mengeringkan sampel di dalam oven antara kisaran suhu $100^{\circ} \mathrm{C}-105^{\circ} \mathrm{C}$ sampai di peroleh berat yang tetap dari sampel yang di ujikan. Langkah kerja pengujian kadar air yaitu: a) dengan menggunakan oven di gunakan untuk sampel yang memiliki kadar air kurang dari $0,1 \%$, b) cawan yang akan di gunakan dikeringkan ke dalam oven selama 15 menit, hal ini diperlukan untuk memperoleh berat cawan yang konstan, c) angkat cawan dengan menggunakan penjepit lalu didinginkan ke dalam desikator selama 15 menit, d) setelah 15 menit ambil cawan kembali dengan menggunakan penjepit dan timbang berat cawan kosong sebagai berat cawan awal, e) kemudian masukan tanah ke dalam cawan sebanyak 10 gram dan mengeringkan dalam oven dengan suhu $105^{0}$ selama 24 jam, setelah 24 jam ambil cawan dan mengeringkan didalam desikator selama 15 menit, f) angkat cawan dari desikator dan ditimbang berat cawan dan sampel setelah proses pengeringn kemudian dicatat berat akir cawan yang berisi sampel.

\section{Analisis Data}

$\begin{array}{lrr}\text { Sampel tanah yang diambil } \\ \text { dianalisis secara kualitatif } & \text { untuk } \\ \text { mendapatkan data sifat fisik tanah. Data } \\ \text { sifat fisik tanah yang telah didapat } \\ \text { dianalisis secara deskriptif untuk } \\ \text { menggambarkan sifat fisik, lalu }\end{array}$


dideskripsikan dan membandingkan dengan karakteristik sifat fisik tanah.

\section{HASIL DAN PEMBAHASAN}

\section{Tekstur Tanah Di Lahan Ubi Kayu}

Berdasarkan hasil penelitian menunjukkan bahwa kondisi tekstur tanah yang ada dilahan ubi kayu yaitu bertekstur liat berlempung. Jenis tanah yang bertekstur liat berlempung membutuhkan cara pengolahan yang lebih baik agar tanaman ubi kayu yang dibudidayakan dapat memberi hasil yang optimal. Tanah yang bertekstur liat ini terasa halus melekat/lengket sehingga mudah menempel dan mudah dibuat dalam bentuk bola. Hasilnya dapat dilihat pada Tabel 1 berikut:

Tabel 1. Hasil Analisis Tekstur Tanah pada Lahan Ubi Kayu Di Desa Wologai Tengah

\begin{tabular}{llllll}
\hline No & Kode Sampel & \multicolumn{3}{c}{ Untuk Tekstur Tanah \% } & Kelas Tekstur \\
\cline { 3 - 5 } & & Pasir & Debu & Liat & \\
\hline 1. & S 1 & 13,33 & 33,33 & 53,34 & Liat Berlempung \\
2. & S 2 & 11,76 & 29,42 & 58,82 & Liat Berlempung \\
3. & S 3 & 17,64 & 5,88 & 76,48 & Liat Berlempung \\
4. & S 4 & 9,00 & 18,28 & 72,72 & Liat Berlempung \\
5. & S 5 & 18,75 & 6,25 & 75,00 & Liat Berlempung \\
\hline
\end{tabular}

Keterangan : S1: Sampel, S2: Sampel 2, S3: Sampel 3, S4: Sampel 4, S5: Sampel 5

Tabel 1 menjelaskan bahwa hasil penelitian tekstur tanah terdiri dari 3 fraksi yakni : pasir, debu dan liat. Masing-masing fraksi memiliki 5 sampel tanah yang setiap sampel persentase berbeda - beda. Tekstur liat $\mathrm{S} 1=$ $53,33 \%, \mathrm{~S} 2=58,82 \%, \mathrm{~S} 3=76,47 \%, \mathrm{~S} 4=$ $72,72 \%$, dan S5 $=75,00 \%$. Tekstur pasir $\mathrm{S} 1=13,33 \%, \mathrm{~S} 2=11,76 \%, \mathrm{~S} 3=17,64 \%$, $\mathrm{S} 4=9,09 \%$, dan S5 $=18,75 \%$. Tekstur debu $\mathrm{S} 1=33,3 \%, \mathrm{~S} 2=29,41 \%, \mathrm{~S} 3=$ $5,88 \%, \mathrm{~S} 4=18,18 \%$, dan $\mathrm{S} 5=6,25 \%$. Hal tersebut menunjukan bahwa kondisi tanah pada lahan ubi kayu di desa wologai tengah termasuk tanah yang ideal atau tanah yang tergolong. Ciri tanah bertekstur liat yaitu $>35 \%$ kemampuan menyimpan air dan hara tanah tinggi, air yang ada diserap dengan energi yang tinggi, maka ketersediaan air cukup untuk kebutuhan tanaman (Mahi, 2013). Jenis tanah yang bertekstur pasir juga tanah yang cocok untuk membudidayakan ubi kayu karena $<40 \%$ sebagian pori berukuran besar sehingga airasinya baik, serta daya hantar air cepat (Islami dan Utomo, 1995). Jenis tanah yang bertekstur debu bisa membebaskan sejumlah hara, sehingga tanah bertekstur debu umunya lebih subur di banding tanah bertekstur pasir. Dari penjelasan ini menunjukan bahwa fraksi pasir dan debu lebih berperan secara fisik.

\section{Struktur Tanah Di Lahan Ubi Kayu \\ Struktur tanah dengan mudah di} tentukan di mana struktur tanah ini dapat di amati secara langsung di lapangan pada lahan ubi kayu disajikan dalam Tabel 2. Pada Tabel 2 menujukkan hasil penelitian 
yang diperoleh struktur tanah yang ada dilahan ubi kayu yaitu struktur tanah gumpal bersudut. Dimana struktur tanah gumpal bersudut saling berhubungan dengan partikel pasir, debu dan liat relatif tersusun satu sama lain, karena di dalam tanah memiliki udarah dan air untuk proses perkembangan dan pertumbuhan tanaman yang ada. Hal ini dikemukakan oleh Ahmad (2009) menyatakan struktur tanah gumpal bersudut juga mempunyai ruang pori yang sedikit besar, jadi tanah yang pori berukuran besar bisa meningkatkan perakaran pada tanaman ubi kayu (Ahmad, 2009).

Tabel 2. Hasil Analisis Struktur Tanah Pada Lahan Ubi Kayu Di Desa Wologai Tengah.

\begin{tabular}{ccc}
\hline No & Kode Sampel & Kriteria \\
\hline 1. & S 1 & Gumpal bersudut \\
2. & S 2 & Gumpal bersudut \\
3. & S 3 & Gumpal bersudut \\
4. & S 4 & Gumpal bersudut \\
5. & S 5 & Gumpal bersudut
\end{tabular}

Keterangan : S1: Sampel 1, S2: Sampel 2, S3: Sampel 3, S4: Sampel 4, S5: Sampel 5

\section{Warna Tanah Di Lahan Ubi Kayu}

Fisik tanah yang dapat dengan mudah di tentukan dengan warna tanah dimana hal ini dapat diamati langsung dilapangan pada lahan ubi kayu dengan hasil yang disajikan pada Tabel 3 berikut:

Tabel 3. Hasil Analisis Warna Tanah Pada Lahan Ubi Kayu Di Desa Wologai Tengah.

\begin{tabular}{ccc}
\hline No & Kode Sampel & Warna Tanah \\
\hline 1. & S 1 & $2 / 110$ YR Black \\
2. & S 2 & $2 / 210$ YR Very Dark Brown \\
3. & S 3 & $2 / 110$ YR Black \\
4. & S 4 & $2 / 110$ YR Black \\
5. & S 5 & $2 / 110$ YR Black
\end{tabular}

Keterangan : S1: Sampel 1, S2: Sampel 2, S3: Sampel 3, S4: Sampel 4, S5: Sampel 5

Tabel 3 memperlihatkan hasil penelitian yang diperoleh dari warna tanah yang ada di lahan ubi kayu adalah 2/1 10 YR black, warna tanah yang diperoleh di lahan ubi kayu sangat cocok untuk dibudidayanan tanaman salah satunya ubi kayu, karena tanah yang berwarna hitam mengandung bahan organik yang tinggi, sehingga bisa memperoleh hasil yang optimal (United States Departement Of Agriculture, 2000)

Pada kondisi tertentu warna tanah juga dijadikan indikator kesuburan atau produktivitas lahan. Warna tanah juga dapat dipengaruhi oleh kandungan bahan organik tanah. Tanah yang mengandung bahan organik tinggi $3,01 \%$ akan berwarna gelap, sebaliknya semakin 
rendah $1,0 \%$ kandungan bahan organik maka tanah akan berwarna semakin terang akumulasi dari bahan organik akan menciptakan warna kehitaman pada suatu tanah atau lahan (Widyati dan Rostiawati, 2010). Warna gelap pada tanah umumnya disebabkan juga oleh kandungan tinggi dari bahan organik yang terdekomposisi (Mahi, 2013).

\section{Kadar Air Tanah Di Lahan Ubi Kayu}

Berdasarkan hasil penelitian yang telah diperoleh kadar air yang ada di lahan ubi kayu sebesar 37,4 \%, dari hasil yang diperoleh dinyatakan bahwa kadar air yang terdapat di lahan ubi kayu tidak sesuai (tidak subur) dimana kadar air ini tidak dapat meningkatkan hasil produksi ubi kayu yang optimal, karena evaporasi/penguapan terhalangi oleh tanaman yang ada disekitar. Kadar air merupakan banyaknya air yang terkandung dalam tanah yang dinyatakan dalam persen (Arifin, 2011). Kadar air yang ideal $50 \%-80 \%$, seandainya kadar air < 50\% - 80\% akan mengakibatkan kerusakan pada akar tanaman ubi kayu dan akar tersebut menjadi keras dan berkayu sehingga banyak mengandung serat, karena kandungan air rendah, sebaliknya $>50 \%$ - $80 \%$ kandungan air sangat tinggi sehingga mengakibatkan hasil produksi ubi kayu menurun dan tdak mendapatkan hasil yang optimal (Rahman, 2015).

Dari hasil penelitian kadar air yang diperoleh ada kaitan dengan tekstur tanah, rendahnya kadar air pada tanaman ubi kayu karena tekstur liat tanah lebih tinggi dibandingkan dengan kadar air, hal ini terjadi mungkin karena adanya proses evaporasi/penguapan langsung melalui tanah atau vegetasi yang ada dilahan ubi kayu. Kadar air tanah juga berhubungan erat dengan porositas tanah, dimana porositas ini memiliki kemampuan tanah dalam menyerap air berkaitan dengan tingkat kepadatan tanah. Semakin padat tanah maka semakin sulit untuk menyerap air maka porositas tanah semakin kecil. Sebaliknya semakin mudah tanah menyerap air maka tanah tersebut memiliki porositas yang besar. Hal ini disebabkan karena kemampuan tanah menyerap air tidak tergantung pada total ruang pori tetapi dipengaruhi oleh persentase sebaran ukuran pori (Yamani, 2007). Kemampuan tanah dalam menahan air dapat dipengaruhi oleh tekstur tanah, tanah-tanah yang bertekstur kasar mempunyai daya tahan air lebih kecil dari pada tanah yang bertekstur halus. Oleh karena itu, tanaman yang ditanam pada tanah kasar umumnya lebih mudah kering dari pada tanah yang bertekstur lempung atau liat

\section{SIMPULAN}

Berdasarkan hasil penelitian karakteristik sifat fisik tanah pada lahan ubi kayu (manihot esculenta crantz) di Desa Wologai Tengah tergolong subur, dapat disimpulkan bahwa: Tekstur tanah yang ada di lahan ubi kayu didominasi oleh tekstur liat, struktur tanah gumpal bersudut, warna tanah 10 YR 2/1 Black dan 10 YR 2/2 Very Dark Brown dan memiliki kadar air 37,4\%. Jenis tanah ini 
merupakan jenis tanah yang ideal atau tergolong sebur untuk membudidayakan tanaman ubi kayu.

Rekomendasi perbaikkan adalah Perbaikkan kadar air sebaiknya petani harus melakukan pemangkasan pada tanaman atau vegetasi yang ada disekitar ubi kayu sehingga proses evaporasi/penguapan tidak terhalangi, sehingga tekstur tanah dan kadar air seimbang dan dapat meningkatkan hasil ubi kayu yang optimal.

\section{UCAPAN TERIMAKASIH}

Pada kesempatan ini penulis ingin mengucapkan terimakasih yang sebesarbesarnya kepada orang tua dan seluruh keluarga, lembaga pendidikan Universitas Flores, Aparat desa Wologai Tengah dan seluruh pihak yang telah membantu kelancaran jalannya penelitian.

\section{DAFTAR PUSTAKA}

Ahmad. 2009 Penentuan Dasar-Dasar Ilmu Tanah. Pengertian Struktur Tanah. Fakultas Pertanian. Bogor

Arifin, Z. 2011. Analisis Nilai Indeks Kualitas Tanah Entisol pada Penggunaan Lahan yang Berbeda. J. Agroteksos 21(1): 47 -54 .

BPS Propinsi, (2015). Badan Pusat Satatistik, Provinsi Nusa Tengara Timur.

Baso, M S. G. Uswah, U. Monde, A., 2014. Variabilitas Sifat Fisika Tanah Dan Corganik Pada Lahan
Hutan dan Perkebunan Kakao (Theobroma Cacao L.) Di Desa Sejahtera Kecamatan Palolo Kabupaten Sigi. e-J. Agrotekbis 2 (6): 565-572.

Buckman, H.O. 1982. Ilmu tanah. Bharatara Karya Aksara. Jakarta. 788 hal.

Defriyanto. 2014. Agihan Sifat Fisik Tanah dan Tingkat Kepekaan Erosinya pada Kawasan Karst di Kecamatan Sukolilo Kabupaten Pati.

Dika, M. T. S. 2011. Sifat fisisk Tanah Pada Hutan Mangrove desa Tolangano Kecamatan Banawa Selatan Kabupaten Donggala Propinsi Sulawesi Tengah. Skripsi Jurusan Kehutanan Fakultas Kehutanan Universitas Tadulako. Palu.

Dwi Priyo Ariyanto, 2010 Dasar-Dasar Ilmu Tanah. PT. Mediyatama Sarana Perkasa: Jakarta.

Ebed De Rosary, 2017 Wologai Kampong Adat Yang Telah Berusia 800 Tahun. Status Berita Lingkungan Ende, Flores.

Elida S, Hamidi W. 2009. Analisis pendapatan agroindustri rengginang ubi kayu di Kabupaten Kampar. Pekanbaru: Fakultas pertanian UIR. JOM FMIPA Volume 1 No. 2 Oktober 2014. 
Hanafiah, A K. 2010. Dasar-dasar Ilmu Tanah. Raja Grafindo Persada:Jakarta.

Hutami, F, D, Harijono. 2014. Pengaruh penggantian larutan dan konsentrasi NaHCO3 terhadap penurunan kadar sianida pada pengolahan tepung ubi kayu. Jurnal Pangan dan Agroindustri. Vol. 18 No. 2 [Agustus 2017] 119-128 2(4):220-230.

Islami, T,dan W.H.Utomo, 1995, Hubngan Tanah Air dan Tanamn. IKIP Semarang Press, Semarang.

Kartasapoetra · 2010. Teknologi Konservasi Tanah dan Air. (Jakarta:Rincka Cipta). Hal. 1012.

Mahi, A.K. 2013. Survey Tanah, Evaluasi dan Perencanaan Penggunaan Lahan.Lembaga Penelitian Universitas Lampung. Hal 219.

Naldo, R.A., 2011. Sifat Fisika Ultisol Limau Manis Tiga Tahun Setelah Pemberian Beberapa Jenis Pupuk Hijaun. J. agroland. Fakultas Pertanian. Universitas Andalas. e-J. Agrotekbis 4 (3) : 227 - 234, Juni 2016 ISSN : 2338-3011.

Noerwijati, S, K, Mejaya, I, M, J. 2015. Penampilan tujuh klon harapan ubikayu di lahan kering masam. Prosiding Seminar Nasional Hasil Penelitian Tanaman Aneka
Kacang dan Umbi Tahun 2015, Bogor, pp. 521-527.

Prihandana R, Hendroko R. 2007. Energi Hijau. Jakarta: Penebar Swadaya. http : // Reposi tory. Unri.ac.id/.

Putra, M.P. 2009. Besar Aliran Permukaan (Run-Off) Pada Berbagai Tipe Kelerengan Di Bawah Tegakan Eucalyptus spp. (Studi Kasus di HPHTI PT. Toba Pulp Lestari, Tbk. Sektor Aek Nauli). Universitas Sumatera Utara, Medan. Jurnal,online Agroekoteaknologi vol. 3. No. 2 : 712 - 723, ISSN No . $2.337-$ 6.597.

Rajamuddin, U. 2009 Kajian Tingkat Perkembangan Tanah Pada Lahan Perswahan Di Desa Kaluku Tinggu Kabupaten Donggala Sulawesi Tengah Jurnal Penelitian Perikanan Agroland 16 (1) : 45-52.

Rusdiana, O., dan R.S. Lubis. 2012. Pendugaan Korelasi antara Karakteristik Tanah Terhadap Cadangan (Carbon Stock) Pada Hutan Sekunder. J. Silvikultur Tropika 3:1:14-21.

Rismayani Ml. 2007 Pemanfaatan dan Pembuatan Tepung Tapioca. Kanisius. Yogyakarta: UGM Press. http : //Reposi tory. Unri.ac.id/. 
Sundari, T., K. Noerwijati, dan I.M. J. Mejaya. 2010. Hubungan antara Komponen Hasil dan Hasil Umbi Klon Harapan Ubi Kayu. Jurnal Balai Penelitian Ubi dan Kacang. Malang. 29(1):2.

Suparman. 2014. Kekerabatn fenetik ubi kayu (manihot esculenta crantz) Di Pulau Ternate Berdasarkan Karakter Morfologi. J. Bioedukasi. 2 (2) : 249 - 255 .

Supryo, H. 2011. Karakteristik sifat fisik dan kimia tanah dibawah 8 jenis tegakan hutan di Wanagamul Gunungkidul Yogyakarta. Laporan DPP UGM (Tidak Dipublikasikan). Fakultas Kehutanan Universitas Gaja Mada. Yogyakarta.

Susilawati, (2008). September 2008 Karakteristik sifat fisik dan kimia ubi kayu (manihot esculenta) Berdasarkan lokasi penanaman dan umur panen berbeda. Jurnal Teknologi Industri dan Hasil Pertanian Volume 13, No. 2.

Rahman, N, Fitriani, H, Hartati, Hartati, N, S. 2015. Seleksi ubi kayu berdasarkan perbedaan waktu panen dan inisiasi kultur in vitro. Pros. Sem Nas. Masy. Biodiv. Indon. 1(18):1761-1765.
Tarigan. C. N., Purba. M., dan Kemala. S. L. 2014. Identifikasi Horizon Argilik dengan Metode Irisan Tipis pada Ultisol di Arboretum USU Kuala Bekala. J. Online Agroteknologi. 2 (2): 863- 877.

United States Departement Of Agriculture 2000. The Color of Soil. (Online) Available at: http://www.nrcs.usda.gov (Accessd 21 Februari 2016).

Utomo, dan S. Prijono. 2014. Implementasi Pemeliharaan Lahan Pada Tanaman Ubi Kayu: Pengaruh Pengelolaan Lahan Terhadap Hasil Taanaman dan Erosi 1:2:88-92.

Wirosoedarmo. R., 2013. Pengaruh Sifat Fisik Tanah pada Konduktivitas Hidrolik Jenuh Di 5 Penggunaan Lahan (Studi Kasus Di Kelurahan Sumbersari Malang). J. AGRITECH. Fakultas Teknologi Pertanian, Universitas Brawijaya. e-J. Agrotekbis 4 (3) : 227 - 234, Juni 2016 ISSN : 2338-3011.

Yamani, A. 2007. Analsis sifat fisik dan kimia tanah pada kelerengan yang berbeda di CV Tabalong Timur Kabupaten Tabalong Kalimantan Selatan Jurnal Universitas Lampung, 8(21): 134- 139. 